\title{
Political Power and the Funding of Politics Lessons for the Materials Research Society from the Experiment of the National Coalition for Science and Technology Philip Speser
}

It is one of the fundamental realities of American politics that political power is relatively easy to obtain; the real problem is keeping the organization financially solvent in periods when there are no political crises.

This statement may sound implausible at first, but the experiment called the $\mathrm{Na}$ tional Coalition for Science and Technology (NCST) confirms it.

\section{What Was NCST?}

NCST was formed shortly after the first Reagan budget was released. Don Stein, Dave Garin, and Sid Katz were congressional fellows sponsored by organizations such as the American Association for the Advancement of Science. During their time as members of congressional committees and senators' and representatives' staffs, they learned firsthand that Congress is responsive to the voice of the people. They also learned that one reason science budgets were being threatened was that the voices of some people, bench scientists and engineers like themselves, were not being articulated.

Concerned about the future of American science and technology, NCST founders decided to embark on a major experiment in the politics of science and technology. They formed NCST, the first registered lobby of bench scientists and engineers focusing on bread-and-butter science and engineering issues. NCST's objectives were to build the political power of scientists and engineers, to convince that com- munity that it was part of its civic responsibility to be politically active, and to fight off budget cuts in federally funded science and technology.

Throughout its eight-year existence, NCST represented between 200 and 1,000 individual scientists and engineers and received support from approximately 40 R\&D-intensive corporations, professional societies, universities, and independent labs. Compared to groups like the AFL$\mathrm{CIO}$ and National Federation of Independent Businesses, NCST was a minuscule organization.

Despite its size, NCST was able to play a central role in the allocations adopted for science functions in the congressional budget resolution. As part of its efforts to build the political power of scientists and engineers, NCST also was central to the enactment of legislation such as P.L. 99502, the Federal Technology Transfer Act of 1986.

\section{NCST and Political Power}

How did NCST obtain power?

The first source of NCST's political power was attention to detail.

In Washington, DC, contacts are not everything, but they certainly help. The way you get and maintain contacts is by walking the halls of Congress to meet with people and by working the phones with people "back home." For years, NCST was there when Senate and House Budget Committee members needed to be visited, their staff educated, letters sent, testimony submitted, and phone calls made to stimulate grassroots pressure. NCST also provided financial support to several friends of science in Congress through honoraria for speeches at NCST's Congressional breakfasts and through direct contributions by its affiliate, SCITEC PAC. Through repeated face-to-face contact, NCST was able to get rapid access to key staff whenever there was a political crisis requiring congressional action.

Persuasion, the art of listening and talking, was NCST's second source of political power.

The importance of listening and talking with our elected officials and their staffs cannot be over-emphasized. I have never met a Member of Congress who did not want to do good for his or her constituents. But most members have no idea of what that "good" is on science and technology issues. Is it better to fund the Superconducting Supercollider or the great NASA observatories? Should NSF put more money into centers or should it place more emphasis on disciplinary programs? Should the federal government increase funding for basic materials research at the National Science Foundation or should it devote more funds to demonstration projects for retraining displaced workers? NCST worked with congressional staff to provide the data required to reach wellthought-out positions on numerous science and technology issues. By providing high quality data and information to staff, NCST became viewed as a resource and its opinion respected.

The third source of NCST's political power was coalition building.

In Federalist "Number 10," James Madison explains that our Constitutional system of checks and balances makes it imperative that interest groups form coalitions in order to enact legislation and implement policies. At NCST, coalition building had two aspects. As the NCST membership ranged from academics to corporate researchers, NCST's network extended into all aspects of the science and technology community in America. Its members enabled NCST policies to be presented to, and adopted by, other organizations. NCST also joined special focus coalitions such as the Ad Hoc Coalition for Biomedical Research in order to lend its voice to their efforts.

\section{NCST and the Funding of Politics}

If NCST was able to attract and successfully exercise political power, why did NCST disband? The answer is money. Poli- 
tics, like materials research, has its real costs. Salaries must be paid, supplies and equipment purchased, and taxes paid. Politically successful, NCST never obtained financial self-sufficiency. It lived off subsidies from its founders and executive directors.

NCST's lack of financial self-sufficiency was a result of inadequate startup capital and its membership strategy. Founded by bench scientists rather than by an established society or association, NCST was a bootstrap operation. All available funds were constantly rolled over into membership campaigns and into a newsletter for members. The lobbying itself was conducted on a pro bono basis.

The problems caused by a lack of startup capital were exacerbated by NCST's membership strategy. This strategy called for building a very large, politically active grassroots organization. To do so, NCST's board chose to keep dues low so as to not inhibit any scientist or engineer from joining. The reasoning was that all scientists and engineers are affected by federal programs. If even $0.05 \%$ of the $4,971,900$ scientists and engineers in the United States would be willing to join an interest group providing them with the means to influence Congress, a sound financial base would be obtained.

It was this reasoning which turned out to be false. NCST's membership ebbed and flowed with the reactions evoked by the administration's science and technology budgets, but NCST was never able to attract more than $0.03 \%$ of the nation's scientists and engineers as members. To understand why, we conducted surveys of potential members. The responses revealed most scientists and engineers are, quite reasonably, more concerned about their research than politics. Unfortunately, this prioritization was correlated with a variety of reasons for not joining a science and technology lobby. Some respondents stated that they did not see a need to join because their professional society was already supporting NCST. Others were concerned about the dues. The chairman of a chemistry department at a major university responded, "My salary has not increased in three years so I cannot afford your $\$ 35$ dues." Yet others thought that joining any exclusively political interest group of scientists and engineers was unprofessional.

\section{The Liquidation of NCST}

Like many innovators in industry, NCST had opened up a "political" market niche only to see much larger, better funded competitors move in. In 1988, NCST's board addressed a painful issue. As an experiment in increasing the political power of bench scientists and engineers, NCST had demonstrated its utility. Indeed, new lobbies, like CORETECH and the Ad Hoc Committee on NSF, were even being founded by associations and universities which had told NCST that they could never see themselves contributing to a lobby. In addition, many professional societies were becoming politically active.

Rather than despair of this state of affairs, NCST welcomed the newcomers as a sign that its experiment in the politics of science was succeeding. More groups lobbying meant more political power for scientists and engineers. Larger coalitions meant more opportunities to protect and increase science and technology budgets. The move of larger organizations into political action meant that the community was finally recognizing its civic responsibility.

Ironically, however, as new organizations entered the political fray and the political power of scientists and engineers grew, the justification for joining NCST decreased. As politics became a legitimate activity for scientists and engineers, scientists and engineers were increasingly likely to seek political representation for their interests through their professional societies. An extensive assessment of its options suggested that NCST could not be financially solvent unless it received an extraordinary infusion of capital for membership building or abandoned its effort to base its funding on membership dues from bench scientists and engineers. Recognizing that the need for a purely lobbying organization of bench scientists and engineers had greatly diminished, NCST's board made the decision to end the experiment.

\section{Lessons for the Materials Research Society}

The federal presence in materials research is pervasive. One indicator suffices: Out of the ten items in the "Research/ Researchers" Department of the October 1/ November 15, 1987 issue of the MRS BULLETIN, nine involved projects or technology being funded by, sold to, or licensed from the federal government. Given the importance of the federal presence, materials researchers must ask how best to address their political interests.

Three lessons for materials researchers emerge from the NCST experiment.

First, political power is relatively easy to create if you are well organized, well represented, and aggressive. Like NCST, through attention to detail, persuasive communication, and coalition building, professional societies like the Materials Research Society can dramatically influence federal policies of interest to their members.

Second, while money certainly is essential, large amounts of it are not vital for political power. Foresight Science \& Technology, Inc. is currently lobbying legislation which would establish a college and university innovation research program at NSF to provide faculty with the opportunities small firms receive through that agency's Small Business Innovation Research program. The bill is being considered by the Senate Commerce Committee for inclusion in the FY 1989 NSF authorization. Earlier this month, Foresight was able to successfully spearhead legislation into law which protects underwater archaeological sites despite the well-funded opposition of treasure salvors. Like NCST, professional societies like the Materials Research Society can be politically effective with modest expenditures.

Third, and perhaps most important, the long-term political influence of bench scientists and engineers is likely to require activism through their professional societies. NCST's experience suggests that political power is best created before it is needed to address a crisis. The current federal budget deficit means science and technology budgets will be a tempting target for years to come. It means that pursuing opportunities for new $R \& D$, education, and technology transfer programs will require laying the groundwork carefully in the Congress and in the White House. Carefully targeted government relations programs initiated by professional scientific societies can provide the political power needed to fight off cuts and exploit opportunities for new funds.

Shortly after he served as the "grand old man" of the Constitutional Convention, Benjamin Franklin wrote to the Duc de la Rochefoucauld: "We are making Experiments in Politicks; what Knowledge we gain by them will be more certain, tho' perhaps we may hazard too much in that Mode of acquiring it."

At the beginning of the Reagan period, the founders of NCST embarked on a new political experiment. Good legislation and federal policy resulted from this experiment. Much also was learned about how to organize political activity by scientists and engineers. This knowledge can be used by the scientific community to design and conduct the next experiments in political representation.

Philip Speser, J.D., PhD, is president of Foresight Science \& Technology, Inc., Washington, DC. 